the Kofler-block and corrected $\left( \pm 2^{\circ}\right)$. Under our conditions the specimen provided had m.p. 116.5$117 \cdot 5^{\circ}$. The same was true of specimen- $A$, made from the Köster-Logemann keto-acetate. Mixtures of the specimens had the same melting point. A full account of the experiments briefly summarized herein will be published in another place.

Prognosis. The synthesis of the tricyclic degradation product undoubtedly opens the way to a total synthesis of cholesterol and its ramifying derivatives. Referring to (II), the configuration of positions 5, 10 , and 9 is secure, and that at 8 is also unlikely to be affected by subsequent changes at 14 and 13 . We now propose to add ring $D$ in a simple manner and hope to obtain two isomerides dependent on the relation of configuration C-13 to C-9. If that is found possible, the total synthesis becomes a matter of routine and eventually will certainly be accomplished. ${ }^{1}$ Carlisle and Crowfoot, Proc. Roy. Soc., A, 184, 64 (1945).

Reich and Reichstein, Helv. Chim. Acta, 26, 2102 (1943); 28, 863 (1945).

${ }^{3}$ Reich, Helv. Chim. Acta, 28, 892 (1945).

${ }^{4}$ Köster and Logemann, Ber. Deut. Chem. Ges., 73, 299 (1940).

s Cornforth and Robinson, J. Chem. Soc., 676 (1946).

- Sen and Mondal, J. Ind. Chem. Soc., 5, 609 (1928).

\section{PESTS OF STORED FOODS FOOD AND AGRICULTURE ORGANISATION CONFERENCE}

$\triangle$ MEETING of scientific workers concerned with $A$ pests of stored food was held in London in the week of August 4. The meeting was opened by Sir John Boyd Orr, director-general of the Food and Agriculture Organisation, who urged the delegates to propose methods which would enable Governments to preserve the 1947 harvest.

The subjects discussed included the appraisal of food losses; the spread of pests throughout the world; specific methods of control of insects and mites, of rodents and of fungi; storage methods ; the world supply position of poisons ; the dissemination of knowledge; and research needs. The chair was taken throughout by W. McAuley Gracie (United Kingdom), who contributed the opening paper on the economic significance of infestation. Most of the scientific papers were on the control of insects and mites. R. T. Cotton (United States) and H. E. Gray (Canada) presented comprehensive studies on the preservation of cereals from insect attack during storage. J. A. Freeman (United Kingdom) gave an account of world foci of infestation and channels of its dissemination, with suggestions for detection and standards of inspection. Prof. R. Mayné (Belgium) spoke on conditions and control methods in his country; R. Attia (Egypt) on conditions in both modern and ancient Egypt; K. R. Sontakay and H. S. Pruthi (India) on traditional Indian methods of storage and on modern rat-proof construction; Prof. P. Vayssière (France) on the principle of airtight ensilage. A detailed account of the methods of grain drying was given by T. A. Oxley (United Kingdom).

On rodents, E. R. Kalmbach (United States) sent a paper on rodent control in the United States, and S. A. Barnett (United Kingdom) gave an account of the principles of rodent control based on the work carried out in Britain during the War.

The secretary of the Conference, S. S. Easter (Food and Agriculture Organisation), gave a report on estimates of losses due to infestation of stored foods. It was agreed that it is quite impracticable to give any reliable estimate of losses for any large area. Various estimates were quoted, including the statement that 10 per cent of the world's stored food is destroyed by pests. It was, however, considered that all such estimates are likely to be below the mark, owing to the high proportion of food stored in small lots by peasant farmers and not entering world trade.

The methods of insect control include fumigation, spraying and dusting, as well as preventive measures such as grain-drying and improvement of hygiene and of building construction. The committee on grain-drying urged that a world-wide study of this problem should be made, so that improved methods could be devised for each area. Economic as well as technical problems are involved, since drying grain reduces its weight; and if the grain is sold by weight, this may entail loss to the producer.

For rodents, the sub-committee urged the general adoption of the method of poisoning, preceded by prebaiting with plain bait. This method, based on research at Oxford during the War, can ensure almost complete clearance in most areas if it is rigorously applied. Again, the preventive measures of improvement of hygiene and buildings were recommended; but it was pointed out that in many areas they can be part only of a long-term project.

Inevitably, the meeting became involved in the discussion of wider problems. There was complete agreement that every country needs a pest control organisation with a staff of trained persons, including scientific investigators and operators. International agreement on certain aspects of pest control organisations is also required. This is exemplified by occurrence of the transfer of pests from one country to another by ship. The transport of rats is an old story, and the damage has already been. done. But the transport of some serious insect pests is a recent affair and is still going on. For example, the mill moth (Ephestia kïhniella) was first noticed as a pest of mills in Germany in 1877 ; by about 1900 it had a world-wide distribution, and it now costs the British milling industry alone some thousands of pounds a year for cleaning and fumigation, apart from the losses due to infestation of flour and offals. Similarly, the spider beetle (Ptinus tectus) was unknown in England before 1892. By 1916 it had spread all over the country and is now to be found in every warehouse in Britain. Its original home was probably Tasmania. Neither of these species is to-day often intercepted on imports; but, had an adequate quarantine service been in operation in the late nineteenth century, the entry of both might have been prevented. During the past few years the Government organisation has intercepted insects not hitherto recorded in the United Kingdom, and in some instances previously undescribed species. The delegates of other countries, and notably Belgium and France, recorded experiences similar to those in the United Kingdom.

Within each country the need for a pest control organisation raises a number of problems which have a more general application than to pest control alone. Prof. J. W. Munro (United Kingdom) gave a paper on the dissemination of information. He dealt first with the need for improvement in the information services available to scientific workers, and in particular, of abstracting services. This, as always, commanded general support. He then went on to 
refer to the problem of keeping administrators adequately informed. The extent to which administrators seek, or are given, advice varies greatly in different countries, and at different times in the same country. In times of crisis advice is readily sought, often when it is too late; at other times it may not be sought at all, and if offered, it may be disregarded. The meeting, said Prof. Munro, gave an opportunity of ensuring that scientific opinion was heard in high quarters, and he hoped that the meeting would state the strongest case it could to that end.

Finally, Prof. Munro and many others referred to the need for the education of transporters, warehousekeepers, millers, wharfingers and the general public. A few countries have done a good deal in this direction, and Denmark gave an example by showing an entertaining film illustrating how bad hygiene and ill-kept buildings encourage infestation. At the other extreme there are the backward countries, mainly in the tropics and sub-tropics. The delegate from Siam gave examples of the formidable problem of educating peasant farmers in pest control. It was, however, pointed out that there is much ignorance to be combated even in the more advanced countries, where it is still common to find farmers and traders who believe in spontaneous generation.

Delegates visited the Ministry of Agriculture and Fisheries Infestation Control Division building, the Pest Infestation Laboratory at Slough, a large-scale grain drying plant, an exhibition of food pests at the British Museum (Natural History) and a number of demonstrations on pest control methods.

The Proceedings of the meeting are to be published by the Food and Agriculture Organisation.

\section{S. A. BARNETT}

R. A. Davis

\section{FUEL ECONOMY CONFERENCE OF THE WORLD POWER CONFERENCE}

\section{By Dr. H. E. CROSSLEY \\ Fuel Research Station, Department of Scientific and Industrial Research}

$\mathrm{T}$ HE Fuel Economy Conference of the World Power Conference was opened at The Hague on September 2 by His Excellency Dr. G. W. M. Huysmans, Netherlands Minister of Economic Affairs, who was introduced by Mr. G. J. T. Bakker, chairman of the Conference. Dr. Huysmans welcomed the representatives of thirty-three countries, and told them that the critical world shortage of fuel gave additional importance to the deliberations of the Conference. It was hoped that the exchange of views on many aspects of fuel economy would be helpful to all the nations, and that the personal contacts made at the Conference would lead to collaboration in the future. The official delegates from Groat Britain and France thanked the Dutch authorities for their hospitality, and looked forward to profitable discussions.

The opening speeches were followed by a lecture on "Atomic Energy for Peaceful Purposes", given by Prof. G. J. Sizoo. He pointed out that estimates of the economics of energy production by atomic fission, or of the size or nature of fission plants, are purely speculative, and often optimistic. In his opinion, atomic fission would probably become a supplementary source of energy, rather than a replacement of other sources. The alternatives of peaceful or aggressive use presented a challenge to mankind.

The first technical session of the Conference was a discussion of reports from nineteen countries on "Fuel Economy since 1939". 'These reports indicated the need for the direction of all fuels to the uses for which they are most suitable, to avoid many operational troubles and to provide higher efficiencies. The British report was appreciated for the account of ways by which the public have been informed of the more efficient use of fuels. A resolution was passed asking the International Executive Council of the World Power Conference, in consultation with the national committees, to consider the collection of target values for energy consumption per unit of product or elfort, for discussion and publication. This resolution was later approved in principle by the International Executive Council.

Subsequent sessions were more specialized in character, as indicated by the following examples.

One session was concerned with liquid fuels, the subject of seven papers. The papers and the discussion showed the great interest in home production of liquid fuels from indigenous sources such as shale, oil sands, tar oil and wood. The commercial development of indigenous sources is, of course, dependent on the cost of imported fuels, and the quantities available for import. Dr. W. H. Zaaijer directed attention to the difficulty in several European countries of preparing motor spirit with a sufficiently high octane number, and suggested that production plants would have to be modernized to meet this demand.

In a session concerned with domestic appliances, the main subject of discussion was the desirability of having quality marks stamped on such appliances. These quality marks would be defined by standard specification of performance and design, and in consequence domestic appliances would be more efficient, and should be cheaper, due to the standardization of parts. It was felt that co-operation between appliance manufacturers and gas companies would be the bost way of sponsoring advancements in the design of gas appliances. Co-operation is needed also between the gas and electricity industries, to avoid the production of undesirable appliances purely for competitive purposes.

The use of fuels for transport purposes was discussed in another session. Papers from Sweden and France showod the wastefulness of steam traction compared with electrical traction, the former requiring $2 \cdot 5-3 \cdot 25$ times the amount of coal needed by the latter for the same load. In the United States Diesel traction is being favoured, particularly for branch line and shunting operations.

The session concerned with industrial and agricultural appliances received the largest number of contributions, twenty papers being submitted for discussion. These papers dealt with a variety of subjects, such as the use of low-grade fuels in various types of boilers and other furnace plant, the recovery of heat from waste liquors, the development of the gas turbine, and the significance of convection and radiation in heating by gas. It was stated that Britain alone had been frank in publishing operational troubles with power station boilers, and this frankness had been made possible by the collaboration of power station engineers and boiler manufacturers on the 